UNIVERSIDADE DE SÃO PAULO

FACULDADE DE DIREITO

GUSTAVO DANTAS FERRAZ

\title{
A PROTEÇÃO DO DIREITO FUNDAMENTAL À VIDA E AS PESQUISAS COM CÉLULAS-TRONCO EMBRIONÁRIAS HUMANAS NO ORDENAMENTO JURÍDICO BRASILEIRO
}

DISSERTAÇÃO DE MESTRADO

São Paulo 


\section{A PROTEÇÃO DO DIREITO FUNDAMENTAL À VIDA E AS PESQUISAS COM CÉLULAS-TRONCO EMBRIONÁRIAS HUMANAS NO ORDENAMENTO JURÍDICO BRASILEIRO}

Dissertação desenvolvida junto ao Departamento de Direito de Estado da Faculdade de Direito da Universidade de São Paulo, sob a orientação do Professor Titular Enrique Ricardo Lewandowski, como exigência parcial para obtenção do título de Mestre em Direito. 


\section{RESUMO}

A dissertação trata do debate acerca do início da proteção do direito à vida e as consequências dessa proteção em relação às pesquisas com células-tronco embrionárias humanas, autorizadas no ordenamento jurídico brasileiro pelo artigo $5^{\circ}$, da Lei $\mathrm{n}^{\mathrm{o}}$ 11.105/2005, julgada constitucional pelo Supremo Tribunal Federal em sede de controle concentrado de constitucionalidade. A abordagem, que se concentrou no estudo da doutrina, legislação e jurisprudência, tem caráter preponderantemente dogmático jurídico, nas dimensões analítica, empírica e normativa. As principais conclusões são as seguintes: o direito à vida garantido pela Constituição Federal, estruturalmente, consiste em um princípio, com âmbito de proteção amplo, ensejando a necessidade de sopesamento com outros valores protegidos pelo ordenamento jurídico para sua aplicação; dentre as possíveis interpretações acerca do que consiste esse direito, ele pode ser considerado como um direito à própria existência, um direito à vida digna e um direito à proteção em face do desenvolvimento da biotecnologia; o início da proteção do direito à vida e as pesquisas e terapias com células-tronco embrionárias são disciplinados no direito brasileiro por dispositivos internacionais e nacionais, tais como a Convenção Americana de Direitos Humanos, a Constituição Federal e a Lei $n^{0} 11.105 / 2005$; o fato de o Supremo Tribunal Federal ter considerado constitucional o artigo $5^{\circ}$, da Lei $\mathrm{n}^{\mathrm{o}} 11.105 / 2005$, em sede de controle concentrado, não afastou a aplicação da Convenção Americana de Direitos Humanos (a qual contém norma que protege o direito à vida, em geral, desde a concepção) e nem impediu um controle estatal e internacional efetivo sobre as pesquisas e terapias com células-tronco embrionárias a fim de resguardar, dentre outros aspectos, o direito à vida em um enfoque transindividual.

Palavras-chave: Direito à vida. Princípio. Início da proteção. Células-tronco embrionárias humanas. Direito à existência. Vida digna. Biotecnologia. Convenção Americana de Direitos Humanos. Lei ${ }^{\circ} 11.105 / 2005$. 


\begin{abstract}
The present work deals with the debate about the beginning of the protection of the right to life and the consequences of this protection related to human embryo-based stem cell research, authorized by the Brazilian legal legislation according to the Article 5 of Law no. 11.105/2005, considered constitutional by the Federal Supreme Court in the concentrated model of constitutional control. The approach, centralized in the study of the doctrine, legislation and jurisprudence, is based on a predominantly dogmatic legal nature, in the analytical, empirical and regulatory dimensions. Following are the main conclusions: the right to life grated by the Federal Constitution structurally consists of a principle, with a broad protection scope, that justifies the need of weighting with other values protected by the legal legislation for its application; among the possible interpretations of what this right is consistent of, it can be considered as a right to the existence itself, a right to a decent life and a right to protection facing the development of the biotechnology; the beginning of the protection of the right to human embryo-based stem cell research and therapies are set in the Brazilian Law by national and international precepts, such as the American Convention of Human Rights, the Federal Constitution and the Law $n^{\circ} 11.105 / 2005$; the fact that the Federal Supreme Court considered the Article 5 of Law $\mathrm{n}^{\circ} 11.105 / 2005$, in the concentrated model of constitutional control, did not distract the application of the American Convention of Human Rights (which contains the regulations that protects the right to life, in general, from its conception) neither obstructed an actual state or international control on the human embryo-based stem cell research and therapies in order to protect, among other aspects, the right to life in a transindividual approach.
\end{abstract}

Key words: Right to life. Principle. Beginning of the protection. Human embryo-based stem cell. Right to existence itself. Right to a decent life. Biotechnology. American Convention of Human Rights. Law n ${ }^{\circ} 11.105 / 2005$. 


\section{INTRODUÇÃO}

O tema a ser desenvolvido neste estudo consiste em debater acerca do início da proteção do direito à vida e as consequências dessa proteção em relação às pesquisas com células-tronco embrionárias humanas, autorizadas no ordenamento jurídico brasileiro pelo artigo $5^{\circ}$, da Lei $\mathrm{n}^{\mathrm{o}} 11.105 / 2005$, julgada constitucional pelo Supremo Tribunal Federal em sede de controle concentrado de constitucionalidade (quando do julgamento da ação direta de inconstitucionalidade $\mathrm{n}^{\circ}$ 3510-0-DF, no final de maio de 2008).

Advirta-se, porém, que o estudo não reproduzirá fundamento por fundamento sustentado por cada um dos Ministros ${ }^{1}$, pois isso acabaria por resultar em mero resumo e dificultaria uma visão concatenada da matéria, já que a argumentação do texto restaria cindida em diversas fundamentações não necessariamente interligadas.

Em vez disso, serão expostos alguns temas fundamentais para a compreensão da questão jurídica em foco e, no decorrer desta exposição, serão agregados comentários sobre os votos proferidos no julgamento.

Além disso, embora sejam levadas em conta certas discussões éticas e filosóficas quanto ao que seja a vida ou quando esta se inicia, estas serão apenas o pano de fundo do principal objeto de estudo: o direito à vida, buscando-se uma análise da respectiva estrutura normativa, dos sentidos em relação aos quais tal direito pode ser entendido e, ainda, dos dispositivos legais que podem ser interpretados como indicativos do início de sua proteção, correlacionando-se tudo isso com o debate referente à viabilidade jurídica das pesquisas com células-tronco embrionárias humanas no direito brasileiro.

Registre-se, ainda, que se buscará preponderantemente um estudo do direito interno brasileiro, mas com o acréscimo de referências à disciplina estrangeira sobre a matéria, como julgados da Suprema Corte Americana e do Tribunal Constitucional Federal Alemão a respeito do aborto, além de alguns trabalhos doutrinários acerca do tema. Os tratados internacionais que se refiram à matéria também serão mencionados, especialmente no que pertine à sua importância no ordenamento jurídico interno.

O tema, ainda que sob o enfoque preponderantemente dogmático e fundado no ordenamento jurídico brasileiro, já é bastante complexo, pois tem caráter interdisciplinar, levando em conta que lida com assunto diretamente ligado às ciências biológicas e a discussões bioéticas.

\footnotetext{
${ }^{1}$ Os dez votos utilizados neste estudo foram encontrados na página do STF na internet (www.stf.jus.br.) e obtidos junto aos gabinetes dos Ministros, em Brasília, em virtude do acórdão ainda não ter sido publicado no Diário Oficial.
} 
A pesquisa sobre esse assunto é plenamente justificada em face não só de sua relevância, já que lida com o direito à vida, mas também em virtude de sua repercussão, pois no seu entorno, como dito acima, circundam debates de diversas áreas do conhecimento. Uma interpretação jurídica que signifique a proibição ou permissão de alguma conduta atinente ao tema (como no caso das pesquisas com células-tronco, por exemplo) gera consequências nos mais diversos setores da sociedade, como nos campos da pesquisa científica e saúde pública, ou em sede da doutrina de determinada religião ou concepção fillosófica.

E dentro desse enfoque interdisciplinar - embora preponderantemente jurídico será analisado o debate a respeito da possibilidade, ou não, perante o ordenamento brasileiro, de realizarem-se essas pesquisas com células-tronco embrionárias humanas, o qual se relaciona diretamente com a discussão acerca do início da proteção do direito à vida.

A resolução de tal questionamento no âmbito do ordenamento pátrio enseja várias considerações, que passam por uma análise de normas internacionais (dentre as quais se destaca a Convenção Americana de Direitos Humanos, de 1969 - art. 4, 1), nacionais (notadamente a Constituição Federal de 1988 e a Lei de Biossegurança - Lei nº 11.105, de 24 de março de 2005, art. $5^{\circ}$ ) e de julgado do Supremo Tribunal Federal (a ação direta de inconstitucionalidade $\left.\mathrm{n}^{\circ} 3510-0-\mathrm{DF}\right)$.

No que pertine às normas internacionais, é imprescindível analisar, primeiramente, qual a influência dos tratados internacionais de direitos humanos perante o ordenamento jurídico brasileiro. Para tanto, também são necessárias algumas considerações sobre como um tratado é incorporado ao ordenamento pátrio e qual a posição hierárquica das normas dele decorrentes diante de normas nacionais.

A necessidade da averiguação desses aspectos é imprescindível, por exemplo, para fundamentar uma análise crítica que será feita quanto ao voto de alguns Ministros do Supremo Tribunal Federal no julgamento da ação direta de inconstitucionalidade $\mathrm{n}^{\mathrm{o}} 3510$ 0 -DF, que não consideraram, em sua fundamentação, o art. $4^{\circ}, 1$, da Convenção da Costa Rica, dispositivo de tratado internacional devidamente incorporado ao ordenamento jurídico brasileiro. Isso ocorreu, por exemplo, no voto do próprio relator da ação direta de inconstitucionalidade no $3510-\mathrm{DF}$, o Ministro Carlos Britto.

Além disso, cumpre questionar também sobre como ficou a disciplina das pesquisas com células-tronco embrionárias humanas diante da declaração de constitucionalidade do art. $5^{\circ}$ da Lei $n^{\circ} 11.105 / 2005$, pelo Supremo Tribunal Federal, no julgamento da ação direta 
de inconstitucionalidade $\mathrm{n}^{\mathrm{o}} 3510-0-\mathrm{DF}$, especialmente no que pertine à possibilidade, ou não, de um efetivo controle estatal (e até internacional) quanto a tais pesquisas autorizadas pela lei, a fim de preservar o direito à vida das presentes e futuras gerações.

Por isso, serão inseridas no estudo algumas referências a normas regulamentares atinentes ao tema, como a recente Resolução da Diretoria Colegiada da Agência Nacional de Vigilância Sanitária (RDC) $n^{0}$ 29, de 12 de maio de 2008, que consiste em um regulamento técnico para o cadastramento nacional de Bancos de Células e Tecidos Germinativos (BCTG) e o envio da informação de produção de embriões humanos produzidos por fertilização in vitro e não utilizados no respectivo procedimento.

Em face dessas considerações, as principais questões a serem analisadas no texto da dissertação serão as seguintes: o direito à vida como um princípio, os diversos sentidos atribuídos ao direito à vida e, por fim, a proteção do início da vida humana no debate acerca das pesquisas com células-tronco embrionárias humanas.

Em relação ao direito à vida como um princípio, considerando as normas classificadas em regras ou princípios, o direito à vida expresso no caput do art. $5^{\circ}$ da Constituição Federal será interpretado como tendo a estrutura normativa de um princípio com âmbito de proteção amplo, ensejando para sua aplicação a necessidade de sopesamento com outros valores protegidos pelo ordenamento jurídico.

No que pertine aos diversos sentidos atribuídos ao direito à vida, será exposto que dentre as possíveis interpretações acerca do que consiste o direito à vida protegido pelo ordenamento jurídico brasileiro, ele pode ser considerado como um direito à própria existência, um direito à vida digna e um direito à proteção em face do desenvolvimento da biotecnologia.

Por fim, a proteção do início da vida humana no contexto do debate sobre a pesquisa com células-tronco embrionárias ensejará a abordagem de diversos tópicos.

O primeiro versará sobre esclarecimentos terminológicos a respeito do que se entende por fertilização in vitro, embrião e células-tronco embrionárias. Em seguida, será feita uma explicação sobre dispositivos internacionais e nacionais que influenciam no debate sobre o início da proteção ao direito à vida e as pesquisas com células-tronco embrionárias no direito brasileiro. Ao final, será analisado o julgamento da ação direta de inconstitucionalidade $\mathrm{n}^{\mathrm{o}}$ 3510-0-DF, com comentários centrados, dentre outros aspectos, na relevância da Convenção Americana de Direitos Humanos para solucionar a questão acerca do início da proteção do direito à vida no ordenamento jurídico brasileiro e na 
necessidade de controle das pesquisas com células-tronco embrionárias a fim de resguardar, especialmente, o direito à vida em um enfoque transindividual.

O método de trabalho consistirá na análise da doutrina, legislação e da jurisprudência, não se aplicando ao caso outros métodos (como a estatística, a pesquisa de campo e outros).

A metodologia de abordagem do objeto em foco terá caráter preponderantemente dogmático jurídico, nas dimensões analítica (análise dos conceitos, da relação entre eles, conectando-os com o direito positivo brasileiro), empírica (análise do direito vigente, notadamente no âmbito da jurisprudência) e normativa (com fundamento nas análises anteriores, prescreve-se resposta adequada ao problema enfrentado).

A importância prática da pesquisa ora planejada resulta dessa abordagem multidimensional, a qual permitirá fomentar a discussão sobre o direito à vida e o início de sua proteção, assim como os critérios de resolução dos conflitos que se apresentem nos casos concretos de colisão de tal direito fundamental com outros direitos ou valores constitucionalmente tutelados, fornecendo subsídios para todos aqueles que lidam com direitos fundamentais no âmbito jurisdicional. 


\section{CONSIDERAÇÕES FINAIS}

Nesta última parte do estudo, passa-se a destacar alguns pontos daquilo que foi exposto nos capítulos anteriores.

Primeiramente, nota-se que o debate jurídico em torno dos direitos à vida, à saúde, à liberdade de pesquisa científica, dentre outros, somado ao modelo teórico acerca dos direitos fundamentais aqui adotado ${ }^{2}$, estão a confirmar a assertiva no sentido de que o direito à vida muitas vezes colide com outros direitos fundamentais, ensejando geralmente um sopesamento para a resolução de questões que se apresentem a esse respeito.

E na análise dessas colisões, deve-se considerar que o fato de estar vivo, que se insere no âmbito de proteção do direito à vida, é de extrema importância (pois, dentre outros aspectos, atua como espécie de condicionamento para o gozo de direitos em geral), mas não significa que o direito à vida tenha, de modo abstrato, um valor preponderante em relação aos demais direitos, quando em conflito com esses. A relevância ímpar da vida para os demais direitos, na verdade, trata-se apenas de mais uma dentre outras circunstâncias jurídicas e fáticas a serem consideradas pelo intérprete quando da análise do caso.

Acrescente-se que a definição daquilo que de fato é protegido pelo direito fundamental à vida também não é pacífica.

Neste estudo constataram- $\mathrm{se}^{3}$ três sentidos que podem figurar no âmbito de tal direito, havendo atribuição de significado ao direito à vida como direito à própria existência, direito a uma vida digna e direito à proteção em face dos avanços da biotecnologia.

Tomando isso por base, passou-se a discutir sobre a natureza jurídica do direito à vida, concluindo-se que este se trata, no ordenamento jurídico brasileiro, de um direito humano positivado constitucionalmente como direito fundamental, o que enseja aos tratados internacionais que lhe protejam o nível hierárquico da supralegalidade (embora infraconstitucional), conforme posição majoritária atual do Supremo Tribunal Federal.

Em seguida, discutiu-se sobre a polêmica definição de um aspecto no âmbito de proteção do direito à vida: o momento em que se inicia a proteção jurídica da vida humana.

E na busca de uma solução de tal controvérsia, passou-se a uma análise do julgamento da ação direta de inconstitucionalidade $\mathrm{n}^{\mathrm{o}}$ 3510-0-DF, que debateu a

\footnotetext{
${ }^{2}$ Vide capítulo 1.

${ }^{3}$ Vide capítulo 2.
} 
constitucionalidade do art. $5^{\circ}$ da Lei $\mathrm{n}^{\mathrm{o}} 11.105 / 2005$, referente às pesquisas e terapias com células-tronco embrionárias humanas, diante da proteção constitucional ao direito à vida e à dignidade da pessoa humana.

Como se viu, o Supremo Tribunal Federal considerou, por maioria de votos, que o artigo $5^{\circ}$ da Lei $n^{\circ} 11.105 / 05$, que autoriza a pesquisa e a terapia com utilização de célulastronco embrionárias humanas obtidas durante procedimento de fertilização in vitro, é constitucional, não ofendendo o direito à vida e a dignidade da pessoa humana.

Essa decisão tomada em sede de controle concentrado de constitucionalidade, no entanto, não abordou, na maioria dos votos apresentados, o artigo $4^{\circ}, 1$, da Convenção Americana de Direitos Humanos, dispositivo de nível supralegal, internalizado em 1992, o qual dispõe que "toda pessoa tem direito a que se respeite sua vida" e, ainda, que "esse direito deve ser protegido pela lei e, em geral, desde o momento da concepção."

A ausência de menção a tal dispositivo não significa, todavia, que este jamais deva incidir, após tal julgamento, em casos concretos que remetam sua solução à análise a respeito do início da proteção do direito à vida no ordenamento jurídico brasileiro. Em vez disso, conclui-se que o art. $4^{\circ}, 1$, da Convenção Americana de Direitos Humanos pode perfeitamente incidir em casos atinentes a tal tema.

Isso porque uma averiguação das fundamentações dos votos dos Ministros no julgamento da ação direta de inconstitucionalidade $n^{\circ} 3510-0-D F$ está a indicar que não se afastou, expressamente, a incidência do artigo $4^{\circ}, 1$, do Pacto de San Jose da Costa Rica.

Além disso, em tal julgamento também não se fixou, de modo impositivo, posição majoritária acerca de quando se inicia a vida ou sua proteção jurídica no ordenamento jurídico brasileiro, levando a concluir que vale o contido no enunciado do artigo $4^{\circ}, 1$, do referido Pacto, acima transcrito, até porque caso se concluísse o contrário isso não isentaria o Brasil, no caso de descumprimento da norma, de eventual responsabilização perante a Corte Interamericana de Direitos Humanos, a cuja jurisdição obrigatória o Brasil se submete.

Ademais, conforme já consignado alhures neste estudo, cabe ressaltar que a proteção do direito à vida, nos diversos sentidos que lhe são atribuíveis, está a fundamentar a necessidade de controle estatal (e até supraestatal) das pesquisas com células-tronco embrionárias humanas, a fim de evitar que tais pesquisas, em vez de beneficiar a vida, a saúde e, enfim, incrementar a qualidade de vida das pessoas em geral, impliquem risco a tais valores diante de eventual má condução das investigações científicas ou tratamentos 
decorrentes. Deve-se evitar que, sob pretexto de atuação conforme a liberdade científica, violem-se diversas outras normas jurídicas protegidas no direito interno e internacional.

Lembre-se que o desenvolvimento de pesquisas científicas, a par das promessas de progresso, curas e outros benefícios, também ensejam riscos e danos a outros valores protegidos pelo ordenamento jurídico. Não se trata de mera cogitação de riscos imaginários, mas, sim, de potencialidade de danos concretos.

Exemplifique-se, no que pertine às pesquisas com células-tronco humanas, com caso divulgado na imprensa de que, na Rússia, terapia com células-tronco sem as cautelas devidas fez com que uma pessoa desenvolvesse tumores no cérebro e na medula espinhal. ${ }^{4}$ Aliás, divulgou-se também que atualmente existem ao menos duas centenas de clínicas em países como China, Rússia e Ucrânia que utilizam células-tronco para o tratamento das mais diferentes doenças sem seguir, com rigor, os protocolos da comunidade científica em geral que atestem a segurança dessas terapias em seres humanos.

O controle estatal efetivo ${ }^{5}$, portanto, é juridicamente fundamentado e imprescindível. Esse controle deve buscar, logicamente, não a proibição ou inviabilização das pesquisas com células-tronco embrionárias humanas, as quais já foram permitidas pela legislação - que o Supremo Tribunal Federal declarou constitucional -, mas sim uma proteção eficaz dos valores juridicamente protegidos (como o direito à vida, à saúde, a dignidade da pessoa humana, dentre outros) e que podem ser eventualmente afrontados por meio de tais pesquisas.

Desse modo, nota-se que o valor vida humana, na posição defendida neste estudo, deve ser protegido no ordenamento jurídico brasileiro sob o enfoque de sua sacralidade ${ }^{6}$, especialmente no que pertine à adoção de medidas de precaução atinentes ao direito à vida em seu sentido transindividual e por preconizar uma proteção relativa da vida desde a concepção, mas com o tempero da instrumentalidade, notadamente em relação à permissão de pesquisas e terapias com células-tronco embrionárias humanas - dentro dos marcos regulatórios nacionais e internacionais - para o alívio do sofrimento e melhoria da saúde das pessoas e da humanidade, concretizando aquilo que é preconizado pela Declaração Universal do Genoma e Direitos Humanos (artigo 12, b).

\footnotetext{
${ }^{4}$ Conforme noticiado na revista Veja, edição 2101, ano 42, no 8, de 25/02/2009, p. 82.

${ }^{5}$ Além de um controle internacional concomitante.

${ }^{6}$ Sobre a sacralidade e instrumentalidade do valor vida humana, explicadas por Dworkin, vide capítulo 2.
} 


\section{REFERÊNCIAS BIBLIOGRÁFICAS}

ACCIOLY Hildebrando; NASCIMENTO E SILVA G. E. do; CASELLA, Paulo Borba. Manual de Direito Internacional Público. 16a ed., São Paulo: Saraiva, 2008.

AITH, Fernando. Curso de Direito Sanitário - A Proteção do Direito à Saúde no Brasil. São Paulo: Quartier Latin, 2007.

ALARCÓN, Pietro de Jesús Lora. Patrimônio Genético Humano e sua proteção na Constituição Federal de 1988. São Paulo: Método, 2004.

ALEXY, Robert. Teoria del Discurso y Derechos Humanos. Trad. Luis Villar Borda. Colômbia: Universidad Externado de Colômbia, 1995.

. El Concepto y La Validez Del Derecho. Barcelona: Gedisa Editorial, 1997.

. Teoria de los Derechos Fundamentales, Trad. Ernesto Garzón Valdés, Madrid, Centro de Estúdios Políticos y Constitucionales, 2002.

. Epílogo a La Teoria de Los Derechos Fundamentales. Trad. Carlos Bernal Pulido, Madrid: Centro de Estúdios Políticos y Constitucionales, 2004.

. Derechos Fundamentales y Estado Constitucional Democrático. In: CARBONELL, Miguel. Neoconstitucionalismo(s). Madrid: Editorial Trotta, 2005.

Malheiros, 2008a.

. Teoria dos Direitos Fundamentais. Trad. Virgílio Afonso da Silva, São Paulo:

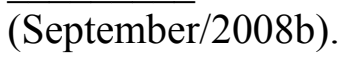

. On the Concept and the Nature of Law. In Ratio Júris, Vol. 21, $\mathrm{n}^{\mathrm{o}} 3$,

ALMEIDA, Silmara Juny de Abreu Chinelato e. Reprodução Humana Assistida: Aspectos Civis e Bioéticos. Tese de concurso à Livre-Docência do Departamento de Direito Civil da Faculdade de Direito da Universidade de São Paulo, São Paulo: Setembro de 2000a.

Tutela Civil do Nascituro. São Paulo: Saraiva, 2000b.

AMARAL JÚNIOR, Alberto (org.), PERRONE-MOISÉS, Cláudia (org.). $O$ Cinquentenário da Declaração Universal dos Direitos do Homem. São Paulo: Edusp, 1999.

ANDREIUOLO, Inês da Mata; ARAUJO, Nádia. A Internalização dos Tratados no Brasil e os Direitos Humanos, in ARAUJO, Nadia e BOUCAULT, Carlos Eduardo (orgs.). Os Direitos Humanos e o Direito Internacional. Rio de Janeiro: Renovar, 1999.

ARAUJO, Luiz Alberto David; NUNES JÚNIOR, Vidal Serrano. Curso de Direito Constitucional. $6^{\text {a }}$ ed., São Paulo: Saraiva, 2002. 
AVELINO, Daniel; DINIZ, Débora. Cenário Internacional da Pesquisa em Células-tronco Embrionárias. Revista Saúde Pública. Brasília, 2008. Disponível em $<$ http://www.scielo.br/pdf/rsp/2009nahead/414.pdf $>$. Acesso em 18-05-2009.

ÁVILA, Humberto. Teoria dos Princípios - Da Definição à Aplicação dos Princípios Jurídicos. $8^{\mathrm{a}}$ ed., São Paulo: Malheiros, 2008.

AZEVEDO, Antonio Junqueira de. Caracterização Jurídica da Dignidade da Pessoa Humana. In RT 797 (2002), pp. 11-26.

BARROS, Sergio Resende de. Direitos Humanos paradoxo da civilização. Belo Horizonte: Del Rey, 2003.

Três Gerações de Direitos. S.1., s.a. Disponível [on-line] em <http://www.srbarros.com.br/artigos $>$. Acesso em 07-07-2007.

BARROSO, Luís Roberto. Gestação de Fetos Anencefálicos e Pesquisas com Célulastronco: Dois Temas acerca da Vida e da Dignidade na Constituição. In GALDINO, Flávio; SARMENTO, Daniel (orgs.). Direitos Fundamentais: Estudos em Homenagem ao Professor Ricardo Lobo Torres. Rio de Janeiro-São Paulo- Recife: Renovar, 2006, pp. 669-708.

Pedido de Ingresso como Amicus Curiae Formulado por Movimento em Prol da Vida - Movitae e Razões de Defesa da Constitucionalidade do Art. $5^{\circ}$ da Lei $n^{o}$ 11.105/05. In Boletim de Direito Administrativo - Agosto/2007a, pp. 893-908.

.Em Defesa da Vida Digna: Constitucionalidade e Legitimidade das Pesquisas com Células-Tronco Embrionárias. In SARMENTO, Daniel; PIOVESAN, Flávia (coords.). Nos Limites da Vida: Aborto, Clonagem Humana e Eutanásia sob a Perspectiva dos Direitos Humanos. Rio de Janeiro: Lumen Juris, 2007b.

. Constituição e tratados internacionais: alguns aspectos da relação entre direito internacional e direito interno. In DIREITO, Carlos Alberto Menezes; CANÇADO TRINDADE, Antonio Augusto e PEREIRA, Antonio Celso [coords.]. Novas Perspectivas do Direito Internacional Contemporâneo - Estudos em Homenagem ao Professor Celso D. de Albuquerque Mello. Rio-São Paulo-Recife: Renovar, 2008.

BASTOS, Celso Ribeiro; MEYER-PFLUG, Samantha. A Interpretação como Fator de Desenvolvimento e Atualização das Normas Constitucionais. In SILVA, Virgílio Afonso da (org.). Interpretação Constitucional. São Paulo: Malheiros, 2005, pp. 145-164.

BITTAR, Carlos Alberto. Os Direitos da Personalidade. $3^{\mathrm{a}}$ ed, Rio de Janeiro: Forense Universitária, 1999.

BITTAR, Eduardo Carlos Bianca. Metodologia da pesquisa jurídica. São Paulo: Saraiva, 2001.

e ALMEIDA, Guilherme Assis de. Curso de Filosofia do Direito. $5^{\mathrm{a}}$ ed., São Paulo: Atlas, 2007.

BOBBIO, Norberto. A Era dos Direitos. Trad. de Carlos Nelson Coutinho, Nova ed., Rio de Janeiro: Elsevier, 2004. 
BONAVIDES, Paulo. Curso de Direito Constitucional. 20ª ed., São Paulo: Malheiros, 2007. . O Direito à Paz como Direito Fundamental da Quinta Geração. In Interesse Público 40 (2006).

BRAUNER, Maria Claudia Crespo. Biotecnologia e Produção do Direito - Considerações acerca das Dimensões Normativas das Pesquisas Genéticas no Brasil. In SARLET, Ingo Wolfgang; LEITE, George Salomão (orgs.). Direitos Fundamentais e Biotecnologia. São Paulo: Método, 2008.

BRITTO, Carlos Ayres. As Células-tronco Embrionárias e sua Formatação Constitucional. In MORAES, Alexandre de (coord.). Os 20 Anos da Constituição da República Federativa do Brasil. São Paulo: Atlas, 2009, pp. 561-589.

CHAVES, Antônio. Direito à Vida e ao Próprio Corpo - Intersexualidade, Transexualidade, Transplantes. 2a ed., São Paulo: RT, 1994.

COCHARD, Larry R. Atlas de Embriologia Humana de Netter. Trad. Casimiro García Fernández e Sonia Maria Lauer de Garcia, Porto Alegre: Artmed, 2003.

COMPARATO, Fábio Konder. A Afirmação Histórica dos Direitos Humanos. 5a. ed., São Paulo: Saraiva, 2007.

COSTA, Helena Regina Lobo da. A Dignidade Humana e as Teorias de Prevenção Geral Positiva. Dissertação de Mestrado apresentada à Faculdade de Direito da Universidade de São Paulo em 2003.

CRANSTON, Maurice. Human Rights, Real and Supposed, in HAIDEN, Patrick. The Philosophy of Human Rights - Paragon Issues in Philosophy. St. Paul/United States of America: Paragon House, 2001.

CRETELLA JUNIOR, José. Comentários à Constituição Brasileira de 1988, Vol. I, art. $1^{\circ}$ ao $5^{\circ}$, LXVII. Rio de Janeiro: Forense Universitária, 1988.

DALLARI, Dalmo de Abreu. O que são direitos da pessoa. 10ª ed., São Paulo: Brasiliense, 1994, pp. 7-86 [Coleção Primeiros Passos, 49].

DAMINELI, Augusto; DAMINELI, Daniel Santa Cruz. Origens da Vida. In Estudos Avançados, Vol. 21, nº 59, 2007, pp. 263-284.

DERANI, Cristiane. Direito Ambiental Econômico. $3^{\text {a }}$ ed., São Paulo: Saraiva, 2008.

DIMOULIS, Dimitri, Vida (Direito à), in DIMOULIS, Dimitri (coord.). Dicionário Brasileiro de Direito Constitucional. São Paulo: Saraiva, 2007.

RT, 2006.

; MARTINS, Leonardo. Teoria Geral dos Direitos Fundamentais. São Paulo: 
DONADIO, Nilka Fernandes; DONADIO, Nilson. Reprodução Laboratorialmente Assistida. In PIATO, Sebastião (coord.). Ginecologia - Diagnóstico e Tratamento, Barueri/SP: Manole, 2008.

DWORKIN, Ronald. Taking Rights Seriously. Cambridge-Massachusetts: Harvard University Press, 1978.

Life's Dominion - An Argument About Abortion, Euthanasia and Individual Freedom. New York: Vintage Books ed., 1994. . Is Democracy Possible Here?- Principles for a New Political Debate. New Jersey: Princeton University Press, 2006.

FAGOT-LARGEAULT, Anne. Embriões, células-tronco e terapias celulares: questões filosóficas e antropológicas. In Estudos Avançados, Vol. 18, nº 51, Maio/Agosto 2004.

FARIA, José Eduardo, (org.). Direitos Humanos, Direitos Sociais e Justiça. São Paulo: Malheiros, 1994.

. O Direito na Economia Globalizada. São Paulo: Malheiros, 1999.

. O Futuro dos Direitos Humanos após a Globalização Econômica. In AMARAL JÚNIOR, Alberto do, e PERRONE-MOISÉS, Cláudia (orgs.). $O$ Cinquentenário da Declaração Universal dos Direitos do Homem. São Paulo: Edusp. 1999.

, Globalização, Soberania e Direito. In MAUÉS, Antonio G. Moreira (org.). Constituição e Democracia. São Paulo: Limonad, 2001.

e KUNTZ, Rolf. Qual o futuro dos Direitos?- Estado, mercado e justiça na reestruturação capitalista. São Paulo: Max Limonad, 2002.

. O sistema brasileiro de Justiça: experiência recente e futuros desafios, Revista Quadrimestral de Estudos Avançados da Universidade de São Paulo, Vol. 18, N.51, Maio/Agosto de 2004, pp. 103-125.

FERNANDES, Silvia da Cunha. As Técnicas de Reprodução Humana Assistida e a Necessidade de sua Regulamentação Jurídica. Rio de Janeiro: Renovar, 2005.

FERRAZ, Gustavo Dantas. Aspectos dos Direitos Fundamentais de Solidariedade. In Revista Jurídica do Ministério Público de Mato Grosso 4 (2008).

FERREIRA, Aurélio Buarque de Holanda. Novo Aurélio Século XXI - O Dicionário da Língua Portuguesa. $3^{\text {a }}$. ed. Rio de Janeiro: Nova Fronteira, 1999.

FERREIRA FILHO, Manoel Gonçalves. Aspectos do Direito Constitucional Contemporâneo. São Paulo: Saraiva, 2003.

. Curso de Direito Constitucional. 32a ed., São Paulo: Saraiva, 2006.

. Direitos Humanos Fundamentais. 9a ed. São Paulo: Saraiva, 2007. 
FIGUEROA, Alfonso Garcia. La Teoria del Derecho em Tiempos de Constitucionalismo. In: CARBONELL, Miguel. Neoconstitucionalismo(s). Madrid: Editorial Trotta, 2005.

FREITAS, Juarez. A Melhor Interpretação vs. Única Resposta Correta. In SILVA, Virgílio Afonso [org.], Interpretação Constitucional. São Paulo: Malheiros, 2005.

GALliAN, Dante Marcello Claramonte. Por detrás do último ato da ciência espetáculo: as células-tronco embrionárias. In Estudos Avançados, Vol. 19, nº 55, 2005, pp. 253-260.

GARCIA, Maria. Limites da Ciência- A Dignidade da Pessoa Humana - A Ética da Responsabilidade. São Paulo: RT, 2004.

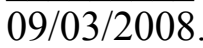

Cabe ao direito estabelecer os limites da ciência. O Estado de São Paulo,

GARNER, Bryan A., e outros. Black's Law Dictionary. $8^{\text {a }}$ ed., St. Paul/United States of América: West, 2004.

GRAU, Eros Roberto, $O$ Direito Posto e o Direito Pressuposto. $6^{\mathrm{a}}$ ed., São Paulo: Malheiros, 2005.

, Ensaio e Discurso sobre a Interpretação/Aplicação do Direito. $5^{\mathrm{a}}$ ed., São Paulo: Malheiros, 2009.

GRINOVER, Ada Pellegrini; BENJAMIN, Antônio Herman de Vasconcellos; FINK, Daniel Roberto; FILOMENO, José Geraldo Brito; WATANABE, Kazuo; NERY JUNIOR, Nelson; DENARI, Zelmo. Código Brasileiro de Defesa do Consumidor - Comentado pelos Autores do Anteprojeto, $7^{\mathrm{a}}$ ed. São Paulo: Forense, 2001.

GUASTINI, Riccardo. La Constitucionalización del Ordenamiento Jurídico: El Caso Italiano. In: CARBONELL, Miguel. Neoconstitucionalismo(s). Madrid: Editorial Trotta, 2005.

GUZ, Gabriela; SEGRE, Marco. Início da vida e células-tronco embrionárias. Folha de São Paulo, 14/07/2005.

HAMMERSCHMIDT, Denise; PRADO, Luiz Regis. A clonagem terapêutica e seus limites de permissibilidade na Lei de Biossegurança brasileira (Lei 11.105/05). In Revista Jurídica do Ministério Público de Mato Grosso 4 (2008).

HART, Herbert L. A. Are There Any Natural Rights? in HAIDEN, Patrick. The Philosophy of Human Rights - Paragon Issues in Philosophy. St. Paul/United States of America: Paragon House, 2001.

HESSE, Konrad. Escritos de Derecho Constitucional - Selección. Madrid: Centro de Estudios Constitucionales, 1983.

JOST, Timothy Stoltzfus. Rights of Embryo and Foetus in Private Law. In The American Journal of Comparative Law, Volume 50, $\mathrm{n}^{\mathrm{o}} 3$ (2002). 
JUBILUT, Liliana Lyra, Os Pactos Internacionais de Direitos Humanos, in ALMEIDA, Guilherme Assis de, e PERRONE-MOISÉS, Cláudia (coords.). Direito Internacional dos Direitos Humanos - Instrumentos Básicos. $2^{\mathrm{a}}$ ed., São Paulo: Atlas, 2007.

LAFER, Celso. A Reconstrução dos Direitos Humanos, um diálogo com o pensamento de Hannah Arendt. São Paulo: Cia das Letras, 1988.

- A Internacionalização dos Direitos Humanos - Constituição, Racismo e Relações Internacionais. Barueri/SP: Manole, 2005.

. O STF e as células-tronco embrionárias. O Estado de São Paulo, 20/04/2008. LEITE, George Salomão, e SARLET, Ingo Wolfgang. Direitos Fundamentais $e$ Biotecnologia. São Paulo: Método, 2008.

LEWANDOWSKI, Enrique Ricardo. Proteção dos Direitos Humanos na Ordem Interna e Internacional. Rio de Janeiro: Forense, 1984.

Direitos Fundamentais. In TAVARES, André Ramos, MENDES, Gilmar Ferreira e MARTINS, Ives Gandra da Silva (coords.). Lições de Direito Constitucional em Homenagem ao Jurista Celso Bastos. São Paulo: Saraiva, 2005.

MARTINS, Ives Gandra da Silva (coord.). Direito Fundamental à Vida. São Paulo: Quartier Latin, Centro de Extensão Universitária, 2005.

MARTINS, Leonardo (org.), Cinquenta anos de Jurisprudência do Tribunal Constitucional Alemão, Berlim: Konrad-Adenauer-Stiftung E. V., 2005.

MELLO, Celso de Albuquerque. $O \xi 2^{\circ}$ do art. $5^{\circ}$ da Constituição Federal. In TORRES, Ricardo Lobo [org.], Teoria dos Direitos Fundamentais. 2a ed., Rio de Janeiro: Renovar, 2001.

MELLO, Romário de Araújo. Embriologia Humana. São Paulo: Atheneu, 2000.

MENDES, Gilmar Ferreira. Direitos Fundamentais e Controle de Constitucionalidade. $3^{\mathrm{a}}$. ed., São Paulo: Saraiva, 2004.

. Jurisdição Constitucional - O Controle Abstrato de Normas no Brasil e na Alemanha. $5^{\text {a }}$ ed., São Paulo: Saraiva, 2005.

MINTIER, Brigitte Feuillet-le. Células-tronco Embrionárias e Direito Francês. In MARTÍNEZ, Julio Luis (org.). Células-tronco humanas - Aspectos Científicos, Éticos e Jurídicos. São Paulo: Edições Loyola, 2005.

MOORE, Keith L.; PERSAUD, T. V. N. Embriologia Clínica. $8^{\mathrm{a}}$ ed., trad. Andréa Monte Alto costa et al, Rio de Janeiro: Elsevier, 2008.

MORAES, Alexandre de. Direitos Humanos Fundamentais. $8^{\text {a }}$ ed., São Paulo: Atlas, 2007.

MYSZCZUK, Ana Paula. Genoma Humano - Limites Jurídicos à sua Manipulação. Curitiba, Juruá, 2005. 
NALINI, José Renato. Filosofia e Ética Jurídica. São Paulo: Revista dos Tribunais, 2008.

NERY JUNIOR, Nelson, e NERY, Rosa Maria de Andrade. Constituição Federal Comentada. São Paulo: Revista dos Tribunais, 2006.

NETO, Luisa. O Direito Fundamental à Disposição sobre o Próprio Corpo - A Relevância da Vontade na Configuração do seu Regime. Coimbra Editora, 2004.

OKARMA, Thomas B. As células-tronco embrionárias humanas: elementos básicos sobre a tecnologia e suas aplicações médicas. In HOLLAND, Suzanne, LEBACQZ, Karen e ZOLOTH, Laurie (orgs.). As células-tronco embrionárias humanas em debate. São Paulo: Loyola, 2006.

PALAZZANI, Laura. O debate sobre as células-tronco na Itália: problemas biojurídicos e desenvolvimento normativo. In MARTINEZ, Julio Luis (org.). Células-tronco humanas: aspectos científicos, éticos e jurídicos. São Paulo: Loyola, 2005.

PIOVESAN, Flavia. Reforma do Judiciário e Direito Humanos. In TAVARES, André Ramos, LENZA, Pedro e ALARCÓN, Pietro de Jesus Lora. Reforma do Judiciário analisada e comentada. São Paulo: Método, 2005.

Saraiva, 2007a .

. Direitos Humanos e o Direito Constitucional Internacional. $8^{\mathrm{a}}$ ed., São Paulo:

, e SARMENTO, Daniel (coords.). Nos Limites da Vida: Aborto, Clonagem Humana e Eutanásia sob a Perspectiva dos Direitos Humanos. Rio de Janeiro: Lúmen Júris, $2007 b$.

PLOMER, Aurora. Direito, ética e política em relação à pesquisa com células-tronco no Reino Unido e nos Estados Unidos. In: MARTÍNEZ, Julio Luis (org.). Células-tronco humanas - Aspectos Científicos, Éticos e Jurídicos. São Paulo: Edições Loyola, 2005.

PONDÉ, Luiz Felipe. Em ação, a máquina moderna da lógica implacável. O Estado de São Paulo, 09/03/2008.

RADBRUCH, Gustav. Filosofia do Direito. $6^{\mathrm{a}}$ ed., trad. L. Cabral de Moncada, Coimbra: Armenio Amado Editor, 1979.

RAMOS, André de Carvalho. Responsabilidade Internacional por Violação de Direitos Humanos. São Paulo: Renovar, 2004.

Teoria Geral dos Direitos Humanos na Ordem Internacional. Rio de JaneiroSão Paulo-Recife: Renovar, 2005.

. O Diálogo das Cortes: O Supremo Tribunal Federal e a Corte Interamericana de Direitos Humanos. In JUBILUT, Liliana Lyra; AMARAL JUNIOR, Alberto do (orgs.). O STF e o Direito Internacional dos Direitos Humanos. São Paulo: Quartier Latin, 2009. 
RAMOS, Elival da Silva. Os Tratados sobre Direitos Humanos no Direito Constitucional Brasileiro Pós-Emenda Constitucional 45/04. In JUBILUT, Liliana Lyra; AMARAL JUNIOR, Alberto do (orgs.). O STF e o Direito Internacional dos Direitos Humanos. São Paulo: Quartier Latin, 2009.

RAMOS, Ricardo Guerlerman Pinheiro. Desenvolvimento Embrionário. In ZAGO, Marco Antonio, e COVAS, Dimas Tadeu (editores). Células-Tronco - A Nova Fronteira da Medicina. São Paulo: Atheneu, 2006.

REALE, Miguel. Filosofia do Direito. 20ª ed., São Paulo: Saraiva, 2007.

REZEK, Francisco. Direito Internacional Público. 11 a ed., São Paulo: Saraiva, 2008.

ROCHA, Renata da. Direito à Vida e a Pesquisa com Células-Tronco, Limites Éticos e Jurídicos. Rio de Janeiro: Elsevier, 2008.

SARLET, Ingo Wolfgang. As dimensões da dignidade da pessoa humana: construindo uma compreensão jurídico-constitucional necessária e possível. In SARLET, Ingo Wolfgang (org.). Dimensões da Dignidade - Ensaio de Filosofia do Direito e Direito Constitucional. Porto Alegre: Livraria do Advogado, 2005.

2007.

. A Eficácia dos Direitos Fundamentais. Porto Alegre: Livraria do Advogado,

SARMENTO, Daniel. Legalização do Aborto e Constituição. In: SARMENTO, Daniel; PIOVESAN, Flavia (coords.). Nos Limites da Vida: Aborto, Clonagem Humana e Eutanásia sob a Perspectiva dos Direitos Humanos. Rio de Janeiro: Lumen Júris, 2007.

SCARPARO, Mônica Sartori. Fertilização Assistida - Questão Aberta - Aspectos Científicos e Legais. Rio de Janeiro: Forense Universitária, 1991.

SHAEFER, Fernanda. Bioética, Biodireito e Direitos Humanos. In MEIRELLES, Jussara Maria Leal de (coord.). Biodireito em Discussão. Curitiba: Juruá, 2008.

SILVA, José Afonso da. Comentário Contextual à Constituição. $2^{\mathrm{a}}$ ed., São Paulo: Malheiros, 2006.

. Curso de Direito Constitucional Positivo. 29a ed., São Paulo: Malheiros, 2007.

SILVA, Reinaldo Pereira e. Introdução do Biodireito: Investigações Político-Jurídicas sobre o Estatuto da Concepção Humana. São Paulo: LTr, 2002.

. Biodireito - A Nova Fronteira dos Direitos Humanos. São Paulo: LTr, 2003.

SILVA, Virgílio Afonso. O proporcional e o razoável, in RT 798 (2002), pp.23-50.

. Princípios e regras: mitos e equívocos acerca de uma distinção. In Revista Latino-Americana de Estudos Constitucionais 1 (2003), pp. 605-627. (org.). Interpretação Constitucional. São Paulo: Malheiros, 2005a. 
- O Conteúdo Essencial dos Direitos Fundamentais e a Eficácia das Normas Constitucionais. Tese apresentada para o concurso de provas e títulos para provimento do cargo de Professor Titular, junto ao Departamento de Direito do Estado - área de direito constitucional - na Faculdade de Direito da Universidade de São Paulo, São Paulo, 2005b.

. A Constitucionalização do Direito - Os Direitos Fundamentais nas Relações entre Particulares. São Paulo: Malheiros, 2005c.

. A evolução dos direitos fundamentais. Revista Latino-Americana de Estudos Constitucionais 7 (2006).

. Direitos Fundamentais, Conteúdo Essencial, Restrições e Eficácia. São Paulo: Malheiros, 2009.

STEINMETZ, Wilson. Princípio da Proporcionalidade e Atos de Autonomia Privada Restritivos de Direitos Fundamentais. In SILVA, Virgílio Afonso da (org.). Interpretação Constitucional. São Paulo: Malheiros, 2005.

SZTAJN, Rachel. Bioética e ortotanásia ou autonomia privada e o direito à vida. In Revista Jurídica do Ministério Público de Mato Grosso 4 (2008).

TAVARES, André Ramos. Curso de Direito Constitucional. $4^{\mathrm{a}}$ ed., São Paulo: Saraiva, 2006 .

THOMSON, Judith Jarvis. A Defense of Abortion. In Philosophy and Public Affairs, Vol. 1, nº 1, Autumn, 1971, Princeton University Press,p. 47-66.

TORRES, Ricardo Lobo (org.). Teoria dos Direitos Fundamentais. $2^{\mathrm{a}}$ ed., Rio de Janeiro: Renovar, 2001.

TOSTA, Jorge. A Relativização da Soberania frente aos Direitos Fundamentais da Pessoa. In JORGE JÚNIOR, Alberto Gosson; COLTRO, Antonio Carlos Mathias; ANDRADE, Marcus Vinícius dos Santos (orgs.). Constituição Federal após 20 anos - Reflexões. Campinas: Millennium, 2009, pp. 171-175.

VASCONCELlOS, Cristiane Beuren. A Proteção Jurídica do Ser Humano In Vitro na Era da Biotecnologia. São Paulo: Atlas, 2006.

VILLAS-BÔAS, Maria Elisa. Da eutanásia ao prolongamento artificial: aspectos polêmicos na disciplina jurídico-penal do final de vida. São Paulo: Forense, 2005.

XAVIER, Dulce. Fé não se impõe. O Estado de São Paulo, 09/03/2008.

WEIS, Carlos. Direitos Humanos Contemporâneos. São Paulo: Malheiros, 2006.

ZAGO, Marco Antonio. Terapia Celular, Transplantes de Células, de Tecidos ou de Órgãos. In ZAGO, Marco Antonio, e COVAS, Dimas Tadeu (editores). Células-Tronco A Nova Fronteira da Medicina. São Paulo: Atheneu, 2006a. 
. Células-Tronco: Origens e Propriedades. In ZAGO, Marco Antonio e COVAS, Dimas Tadeu (editores). Células-Tronco - A Nova Fronteira da Medicina. São Paulo: Atheneu, 2006b.

\section{NOTÍCIAS DE JORNAIS E REVISTAS:}

Stem cell research debate continues - Can we cure disease with embryonic stem cells? And should we?. Harvard University Gazette, 21.04.2005. Disponível em $<$ http://www.hno.harvard.edu/gazette/2005/04.21/01-stem.html $>$. Acesso em 23-03-2009.

Clínica não descarta células preservadas por temor de problemas com a Justiça. Folha de São Paulo, de 09 de março de 2.008.

Ressalvas tornam a lei inaplicável, dizem cientistas. Folha de São Paulo, de 29 de maio de 2008 .

Para CNPq, uso de embrião continuará restrito no país. Folha de São Paulo, 31 de maio de 2008.

A célula da esperança. Revista Veja, edição 2081, ano 41, nº 40, 08 de outubro de 2008.

Uso em humanos: nos EUA, teste deve começar dentro de poucos meses. Folha de São Paulo, 10 de outubro de 2008.

Pesquisadora quer pressa em $1^{\circ}$ teste clínico com células de embrião do país. Folha de São Paulo, 10 de outubro de 2008.

Da Rússia, sem amor. Revista Veja, edição 2101, ano 42, nº 8, 25 de fevereiro de 2009.

Fora do útero. Folha de São Paulo, 29 de março de 2009.

Some Stem Cell Research Limits Lifted, New York Times, de 18 de abril de 2009. Disponível em <http://www.nytimes.com/2009/04/18/health/18stem.html $>$. Acesso em 29/05/2009. 